\title{
TEORI ZAVASCKI, O SUPREMO TRIBUNAL FEDERAL E A RESPONSABILIDADE FISCAL
}

Coluna publicada em 7.2.2017: <https://www.conjur.com.br/2017-fev-07/ contas-vista-teori-zavascki-supremo-responsabilidade-fiscal $>$

O Supremo Tribunal Federal está assumindo responsabilidade cada vez maior sobre as finanças públicas do Brasil.

Atualmente, a interferência do Poder Judiciário em matéria de finanças públicas é uma realidade da qual não se pode afastar. $\mathrm{O}$ controle das finanças públicas está em boa parte nas mãos do Poder Judiciário. Além da intensa e constante interferência nos orçamentos e nas políticas públicas, determinando e/ou modificando a realização de despesas, de forma geral ou individualizada, estão sob julgamento várias questões importantes envolvendo o Direito Financeiro. É o caso das recentes questôes envolvendo as dívidas dos estados, além de outras, fazendo com que a judicialização das finanças públicas tenha se transformado em uma realidade inexorável.

O país todo lamentou a recente e precoce morte do Ministro Teori Zavascki, que ganhou o respeito de todos por sua competente atuação. Estavam em suas mãos as mais importantes decisões em nossa Suprema Corte relacionadas à chamada operação "lava jato", objeto da atenção de todos. O que poucos sabem é que estava sob sua relatoria a maior parte das ações questionando a constitucionalidade de dispositivos da Lei de Responsabilidade Fiscal, e ele havia liberado os processos para julgamento, que estava pautado para a primeira sessão deste ano. Sua morte provocou o adiamento de um julgamento esperado há mais de 16 anos, extremamente importante para definir e dar segurança jurídica às nossas finanças públicas. E que, na atual crise, torna-se ainda mais relevante por afetar a estabilidade econômica. ${ }^{1}$

1 Como bem destaca o editorial do jornal O Globo: "Esta é mais uma pesada dúvida que existe sobre o sucessor do ministro Teori Zavascki, com quem estava este processo. Não dependerá 
A Lei de Responsabilidade Fiscal (Lei Complementar 101/2000) surgiu para atender ao disposto no art. 163 da Constituição, que previa lei complementar para dispor sobre normas gerais de finanças públicas, regulando temas como dívida pública, concessão de garantias por entidades públicas, operações de câmbio feitas pelos entes federados, dentre outras.

Atendeu parcialmente ao comando constitucional, pois regulou apenas parte do art. 163 da Constituição, ignorando o disposto nos incisos V, VI e VII, relacionados à fiscalização financeira da administração direta e indireta, às operações de câmbio feitas pelos entes políticos e às instituições oficiais de crédito da União.

Uma lei para instituir um código de finanças públicas havia sido cogitada por ocasião das discussōes na Assembleia Constituinte de 1988, mas o impulso para sua aprovação após a promulgação da Constituição surgiu apenas com a Emenda Constitucional 19/1998, que fomentou a reforma da administração pública, tendo sido o projeto encaminhado pelo Poder Executivo em 1999 (PLC 18/1999, Câmara dos Deputados, rel. dep. Pedro Novais; PLC 4/1999, Senado, rel. sen. Álvaro Dias e Jefferson Peres). ${ }^{2}$

Promulgada em 5 de maio de 2000, a Lei de Responsabilidade Fiscal teve por objetivo instituir normas de gestão fiscal responsável, mediante "ação planejada e transparente, em que se previnem riscos e corrigem desvios capazes de afetar o equilíbrio das contas públicas, mediante o cumprimento de metas de resultados entre receitas e despesas e a obediência a limites e condições no que tange a renúncia de receita, geração de despesas com pessoal, da seguridade social e outras, dívidas consolidada e mobiliária, operações de crédito, inclusive por antecipação de receita, concessão de garantia e inscrição em Restos a Pagar” (LRF, art. $1^{\circ}, \mathbb{\$} 1^{\circ}$ ). Destacam-se como seus pilares o planejamento, a limitação das despesas, com destaque para as despesas com pessoal e endividamento, e a transparência.

Logo após sua promulgação, a Lei de Responsabilidade Fiscal foi questionada por várias ações diretas de inconstitucionalidade, ${ }^{3}$ com destaque para a ADI 2.238, movida pelos partidos políticos PCdoB, PSB e PT, que se iniciou em julho do mesmo ano. E seguiram-se outras ADIs, como 2.250, 2.256, 2.261, 2.324 e 2.365,

mais do ministro a ser indicado pelo presidente Temer a Lava-Jato, mas sim a própria estabilidade econômica" (Supremo decidirá o futuro da Lei de Responsabilidade Fiscal, O Globo, 5 de fevereiro de 2017).

2 AFONSO, José Roberto Rodrigues. Uma história da lei brasileira de responsabilidade fiscal. Revista Direito Público - RDU, Porto Alegre, edição especial, 2016, p. 128-137.

3 Como já comentado na coluna Irresponsabilidade fiscal ainda persiste, 15 anos após a publicação da lei, publicada em 7 de abril de 2015 e que consta deste livro. 
as Ações Cíveis Originárias 1.023 e 1.056, além da Arguição de Descumprimento de Preceito Fundamental 24. Todas elas estavam pautadas para julgamento em $1^{\circ}$ de fevereiro de 2017, que foi adiado em razão de a maioria estar sob relatoria do Ministro Teori Zavascki. Várias aguardavam julgamento, portanto, há mais de 16 anos, e lamentavelmente uma fatalidade vai atrasar ainda mais decisões tão relevantes para o Direito Financeiro. E justamente em um momento em que as finanças públicas estão em situação crítica, quando se faz ainda mais importante a segurança jurídica que resultaria do julgamento definitivo de dispositivos da LRF que estão sendo questionados.

Vale registrar os principais aspectos dessa discussão, e sobre os quais nossa Suprema Corte deverá - espera-se - em breve se manifestar.

O dispositivo mais atacado é o art. 20 da LRF, objeto de várias das ações citadas, que estabeleceu a limitação de gastos com pessoal para cada um dos poderes e entes da federação, o que, segundo os autores das demandas, ofende o princípio federativo e da separação dos poderes. Havendo previsão no art. 169 da Constituição de que se editasse lei complementar estabelecendo limites para as despesas com pessoal dos entes da federação, a LRF, em seu art. 19, fixou referidos limites, no montante de $50 \%$ da receita corrente líquida para a União, $60 \%$ para os estados e $60 \%$ para os municípios. O art. 20 foi além, especificando, dentro desses limites, os percentuais de cada um dos poderes dos respectivos entes da federação. $\mathrm{O}$ que, segundo os autores das ações mencionadas que o questionaram, violou a Constituição por ferir a autonomia dos entes da federação e o princípio da separação dos poderes, além de ultrapassar os limites que a referida lei teria para regulamentar o tema, que deveria restringir-se a estabelecer apenas normas de caráter geral. Argumentam que o art. 169 da Constituição não admite que se estabeleçam limites por Poder, mas tão somente por esfera de governo. Em 11 de outubro de 2000, concluiu-se o julgamento da medida cautelar, que foi indeferida, por apertada maioria de seis votos contra cinco, tendo o Ministro Marco Aurélio votado pelo indeferimento após retificar seu voto, inicialmente pelo deferimento na sessão anterior (ADI 2.238, sessão de 28.9.2000). Com isso, permaneceu vigente o art. 20 da LRF até a decisão de mérito, que iria ser objeto de debate na sessão do dia $1^{\circ}$ de fevereiro de 2017.

Questionou-se também o disposto no art. $9^{\circ}, \$ 3^{\circ}$, que, ao tratar do contingenciamento das despesas dos poderes se constatada a inviabilidade de cumprimento das metas fiscais, estabeleceu que "no caso de os Poderes Legislativo e Judiciário e o Ministério Público não promoverem a limitação no prazo estabelecido no caput, é o Poder Executivo autorizado a limitar os valores financeiros segundo 
os critérios fixados pela lei de diretrizes orçamentárias". Isso violaria o princípio da separação de poderes, pois daria ao Poder Executivo um "superpoder" de intervir nos demais, substituindo-os nas respectivas avaliações de oportunidade e conveniência, o que afronta o princípio da separação de poderes. Em decisão cautelar, o STF acolheu os argumentos, entendendo que manter tal dispositivo viabiliza a interferência do Poder Executivo na esfera de atuação autônoma dos demais poderes, suspendendo a sua eficácia. ${ }^{4} \mathrm{O}$ tema já foi abordado na Conjur por Luciano Fuck e José Roberto Afonso, que defendem a constitucionalidade da norma, cuja aplicabilidade entendem ser "uma forma de assegurar o tratamento igualitário aos mesmos poderes nas diferentes esferas governos, com a redução dos repasses financeiros se não for aplicada a limitação de empenho".

Outro dispositivo cuja arguição de inconstitucionalidade é bastante relevante é o art. 35, atacado na ADI 2.250, que veda o endividamento recíproco, ou seja, a realização de operações de crédito entre os entes da federação. ${ }^{6}$ Uma vedação que se integra à ideia da responsabilidade fiscal expressa no art. $1^{\circ}$ da lei no sentido de prevenir riscos, uma vez que esse tipo de operação sempre esteve entre as principais causas do descontrole das contas públicas. ${ }^{7} \mathrm{O}$ que se pôde constatar recentemente no caso das "pedaladas fiscais", em que houve violação do art. 36, que previa a mesma vedação, mas entre o ente da federação e a instituição financeira por ele controlada. A questão é polêmica, tendo o autor da ação, o governador de Minas Gerais à época, mostrado que tal proibição prejudicava a gestão de fundos instituídos pelo governo, com recursos obtidos por meio de operações de crédito externo e que eram utilizados para financiar obras e políticas públicas dos municípios mineiros, em setores como saneamento ambiental, desenvolvimento urbano e recuperação de bacias hidrográficas, que estavam trazendo resultados muito positivos. Com a vedação, isso ficaria prejudicado, e estaria sendo afrontada a autonomia estadual, que não mais poderia contar com esse legítimo instrumento de federalismo cooperativo para fomentar o desenvolvimento, o que caracterizaria uma violação ao prin-

4 ADI 2.238, sessão de 22.2.2001.

5 Coluna A Lei de Responsabilidade Fiscal e o STF: limitação de empenho, publicada em 22 de outubro de 2016.

6 “Art. 35. É vedada a realização de operação de crédito entre um ente da Federação, diretamente ou por intermédio de fundo, autarquia, fundação ou empresa estatal dependente, e outro, inclusive suas entidades da administração indireta, ainda que sob a forma de novação, refinanciamento ou postergação de dívida contraída anteriormente."

7 Como já mencionei nos comentários ao art. 35 da LRF na obra coordenada por Ives Gandra Martins e Carlos Nascimento, Comentários à Lei de Responsabilidade Fiscal. 6. ed. São Paulo: Saraiva, 2012. p. 293. 
cípio federativo estampado na Constituição em cláusula pétrea. Em sede de decisão cautelar, os argumentos não prosperaram, e o dispositivo permanece vigente.

A ADI 2.324 pugna pelo reconhecimento da inconstitucionalidade de partes do art. 56 da LRF, ${ }^{8}$ que regula a emissão de pareceres sobre as contas pelos tribunais de contas e prevê a emissão de pareceres separados para cada um dos poderes e instituições independentes. Entende que, da forma como está redigido o caput do dispositivo, retira-se a competência das cortes de contas para julgar as contas dos chefes dos respectivos poderes, em desacordo com o que está estabelecido pelo art. 71, II, da Constituição; e a redação do $\$ 2^{\circ}$ do mesmo artigo dá à comissão mista uma competência não prevista na Constituição, de emitir parecer sobre as contas dos tribunais de contas. É interessante observar, no caso da competência para julgamento das contas dos administradores públicos, nos termos do art. 71, II, que a questão voltou recentemente à discussão no julgamento dos RE 848.826 e 729.744, ocorrido em 10 de agosto de 2016, e que já comentamos neste espaço.?

No contexto da atual crise financeira dos entes da federação, cabe ainda estar atento à interpretação que se vai conferir ao art. 11 da LRF, também questionado na ADI 2.238. Esse dispositivo veda a realização de transferências voluntárias ao ente que deixar de exercer plenamente sua competência tributária - isto é, que deixar de prever e arrecadar os tributos a ele atribuídos pela Constituição. Por tratar apenas de transferências voluntárias, e não de repasses obrigatórios, a decisão liminar entendeu não haver violação ao princípio federativo (sessão de 9/5/2002). Recentemente, no entanto, não foram poucas as vezes em que o Supremo Tribunal deu preferência à continuidade de políticas públicas em detrimento de uma interpretação mais restrita dos requisitos da LRF para o recebimento de transferências

8 “Art. 56. As contas prestadas pelos Chefes do Poder Executivo incluirão, além das suas próprias, as dos Presidentes dos órgãos dos Poderes Legislativo e Judiciário e do Chefe do Ministério Público, referidos no art. 20, as quais receberão parecer prévio, separadamente, do respectivo Tribunal de Contas.

$\$ 1^{\circ}$ As contas do Poder Judiciário serão apresentadas no âmbito:

I - da União, pelos Presidentes do Supremo Tribunal Federal e dos Tribunais Superiores, consolidando as dos respectivos tribunais;

II - dos Estados, pelos Presidentes dos Tribunais de Justiça, consolidando as dos demais tribunais.

$\$ 2^{\circ} \mathrm{O}$ parecer sobre as contas dos Tribunais de Contas será proferido no prazo previsto no art. 57 pela comissão mista permanente referida no $\$ 1^{\circ}$ do art. 166 da Constituição ou equivalente das Casas Legislativas estaduais e municipais."

9 Coluna Supremo gera polêmica ao decidir sobre julgamento de contas de prefeitos, publicada em 23 de agosto de 2016 e que consta neste livro. 
voluntárias (muitos deles previstos fora do art. 11, é verdade). É o caso, por exemplo, das decisões em favor dos estados de Roraima ${ }^{10}$ e de Alagoas, ${ }^{11}$ para citar algumas, suspendendo procedimentos federais que poderiam acarretar o bloqueio das transferências e enfatizando a necessidade de observar o devido processo para o registro nos cadastros de inadimplência. Nesse sentido, a interpretação conferida aos poderes federais de suspensão de transferências voluntárias poderá também ser esclarecida em julgamento definitivo.

Há, enfim, muitas questôes juridicamente interessantes e de grande relevância para a definição das regras que regem as finanças públicas em nosso país, tendo sido destacadas algumas delas. Cada vez mais na ordem do dia, principalmente em situações de crise como essa, em que "casa onde falta pão todos brigam e ninguém tem razão", nossa Suprema Corte está aí justamente para dar segurança jurídica e dizer quem tem razão. Alexandre de Moraes, indicado como novo ministro do STF, embora não tenha assumido os encargos de decidir as questôes da operação "lava jato", tem em suas mãos uma grande responsabilidade.

10 Para viabilizar convênios, STF suspende inscrição de Roraima como inadimplente, publicada em 6 de janeiro de 2017.

11 Alagoas é mais um estado que consegue no STF deixar lista de inadimplentes publicada em 21 de julho de 2016. 